\title{
COMMENTARY
}

\section{Biological markers and diagnosis of ventilator-associated pneumonia}

\author{
Jean-Yves Fagon* \\ See related research by Vanspauwen et al., http://ccforum.com/content/15/1/R14
}

\begin{abstract}
Evaluation of a new biomarker from bronchoalveolar fluid, the Clara cell protein 10, adds data to the search for a diagnostic marker for ventilator-associated pneumonia (VAP). For more than 15 years, investigators tried to identify such a marker for predicting or diagnosing VAP. Unfortunately, the results of a number of these studies are disappointing. For optimal management of critically ill, ventilated patients with clinical suspicion of VAP, clinicians need accurate microbiological information to decide to treat in case of confirmed infection and to guide the initial choice of antibiotic therapy with identification of the responsible pathogen(s). Thus, today, the potential advantages of biomarkers are to improve the rapidity and performance of current diagnostic procedures and to reduce antibiotic exposure and selective pressure.
\end{abstract}

Until now, it has usually been considered that the best way to diagnose and appropriately treat bacterial infection was to identify the bacteria(s) responsible for the infection. This statement is accepted without debate for nearly all infections, whether they are severe (such as meningitis) or not (such as urinary tract infection). The only question is about the delay for obtaining results with the necessity, in some cases, of initiating urgent empirical antibiotic treatment. In contrast, an endless debate exists about the diagnosis of ventilator-associated pneumonia (VAP). This debate is not only about clinical evaluation alone versus clinical suspicion plus microbiological confirmation, but also, in the case of bacteriologic diagnosis, about the choices between invasive and noninvasive methods, bronchoscopic or non-bronchoscopic sampling techniques, and quantitative or non-quantitative

*Correspondence: jean-yves.fagon@egp.aphp.fr

Medical Intensive Care Unit, Hôpital Européen Georges Pompidou, AP-HP and Paris Descartes University, 20 rue Leblanc 75908 PARIS Cedex 15, France bacterial cultures. Recently, the use of biomarkers has been proposed and tested to replace or complete (or both) such techniques [1-4]. VAP is difficult to diagnose in the critically ill patient because of the presence of underlying cardiopulmonary disorders (for example, atelectasis, acute respiratory distress syndrome, congestive heart failure, pulmonary contusion, and pulmonary hemorrhage), the nonspecific radiographic and clinical signs associated with this infection, and the rapid invasion of the normally sterile lower respiratory tract by microorganisms in all patients with an endotracheal tube, requiring that colonization be differentiated from true infection [2]. Actually, there is little information about actual clinical practice; individual studies indicate that practice often differs from recommendations in the literature [5]. In contrast, recommended design features of future clinical trials of antimicrobial agents for VAP - elaborated by the Infectious Disease Society of America, the American Thoracic Society, the Society of Critical Care Medicine, and the American College of Chest Physicians - stress the requirement of appropriate microbiological confirmation of infection by deep lower respiratory tract culture for inclusion in the intention-to-treat population of such trials [6].

These difficulties for diagnosing VAP and identifying responsible pathogen(s) lead to potential over- or underprescription of antibiotics and misguided treatment. The strong associations between delayed diagnosis and subsequent delayed initiation of treatment or between inappropriate initial antibiotic therapy and worse outcome are well documented [7]. On the other hand, a recent observational study conducted in 303 patients at risk for multidrug-resistant pneumonia suggests that guideline-compliant antibiotic treatment was associated with increased mortality in comparison with nonguideline-compliant treatment [8].

The major potential advantage of biomarkers is not to diagnose VAP by itself but to potentially improve the rapidity and performance of current diagnostic procedures. The rationale is to identify and, if necessary, to dose specific markers of alveolar infection (not of bronchial colonization): either endogenous mediators released 
locally by alveolar macrophages activated by microbial products or direct products of parenchymal destruction [9]. A number of biomarkers - including soluble triggering receptor expressed on myeloid cells-1 (sTREM-1) [10], procalcitonin (PCT) [11], copeptin [12], C-reactive protein (CRP) [13], interleukin-1-beta, granulocyte colony-stimulating factor, macrophage inflammatory protein-1-alpha [14], plasminogen activation inhibitor-1 [15], surfactant protein D, receptor of advanced glycation end-products [16], midregional pro-atrial natriuretic peptide [17], and endotoxin [18] or elastin [19] fibers have been tested recently for use in determining the diagnosis and prognosis for patients with suspected or confirmed VAP. Globally, the results of studies evaluating the value of biomarkers in diagnosing VAP are contradictory. Initially, biomarkers - particularly CRP, PCT, and sTREM-1 - were considered to be promising markers for improving diagnostic strategies of VAP. Today, the results of recent studies suggest that the measurement of biomarkers in bronchoalveolar lavage (BAL) fluid appears to have minimal diagnostic value for VAP $[13,20]$.

The article by Vanspauwen and colleagues [1] in the previous issue of Critical Care adds new data to the search for a biomarker for VAP. The investigators evaluated a low-molecular-weight protein secreted in the alveoli, the Clara cell protein 10 (CC-10), which has a possible anti-inflammatory role in humans [1]. Bronchoscopy with BAL was performed in 196 patients who were treated with mechanical ventilation for more than 48 hours and who had clinical suspicion of VAP. The authors found, in the microbiologically confirmed VAP group, a median CC-10 concentration that was significantly higher than in the non-VAP group $(3,019$, range 282 to 65,546 versus 2,054, range 62 to $30,240 \mathrm{ng} / \mathrm{mL}$; $P=0.03)$, but such CC-10 levels are not discriminative for diagnosing VAP. No difference between patients with corticosteroids or antibiotic therapy and those without or between patients with Gram-positive and those with Gram-negative bacteria as responsible pathogens was observed.

In this well-conducted study, some strengths and weaknesses are worth mentioning. First, to evaluate new diagnostic techniques, a reference standard is required. For VAP, because histological confirmation is not a practical reference, quantitative cultures of BAL fluid are the best possible alternatives [2]. Second, bronchoscopy and lavage may be contraindicated in some patients and remain operator-dependent and time-consuming; in addition, high variability in the use of bronchoscopic sampling across intensive care units exists [5]. Third, an ideal diagnostic test for VAP would involve a highly discriminatory, easy-to-sample blood test. In fact, biomarkers potentially used in diagnosing VAP, including
CC-10, are BAL-based techniques, just like quantitative cultures and direct examination of BAL fluid. Consequently, such a new technique is probably an extension of BAL fluid analysis in addition to microbiological techniques rather than a simplification of diagnostic procedures for VAP. Fourth, as usual in this type of study, the precise timing of sampling may influence the diagnosis of VAP. Results of CC-10 dosage in the group of non-VAP patients with a distinction between patients with negative cultures and those with more than 0 and less than $10^{4}$ colony-forming units per milliliter (or less than $2 \%$ intracellular organisms) and data concerning the follow-up of such patients (particularly the occurrence of subsequent pneumonia) could give additional information about the ability of CC-10 dosage to predict VAP. Finally, this study did not include sequential CC-10 measurements, although recent data concerning PCT suggest that serial dosages may be used as a marker to monitor response and possibly to terminate antibiotic therapy [21]. Today, even if interest in surrogate markers (that is, BAL fluid biomarker dosage) to resolve the question of diagnosing or predicting VAP is not demonstrated, interest in the continuing story of biomarkers and VAP is certain.

\section{Abbreviations}

BAL, bronchoalveolar lavage; CC-10, Clara cell protein 10; CRP, C-reactive protein; $\mathrm{PCT}$, procalcitonin; STREM-1, soluble triggering receptor expressed on myeloid cells-1; VAP, ventilator-associated pneumonia.

\section{Competing interests}

The author has received research support from Astellas (Tokyo, Japan) and KaloBios (South San Francisco, CA, USA) and served on an advisory board for sanofi-aventis (Paris, France).

Published: 9 March 2011

\section{References}

1. Vanspauwen MJ, LinssenCFM, Bruggeman CA, Jacobs JA, Drent M, Bergmans DCJ, van Mook WNKA: Clara cell protein in bronchoalveolar lavage fluid: a predictor of ventilator-associated pneumonia? Crit Care 2011, 15:R14

2. Chastre J, Fagon JY: Ventilator-associated pneumonia. Am J Respir Crit Care Med 2002, 165:867-903.

3. Rea-Neto A, Youssef NC, Tuche F, Brunkhorst F, Ranieri VM, Reinhart K, Sakr Y: Diagnosis of ventilator-associated pneumonia: a systematic review of the literature. Crit Care 2008, 12:R56.

4. Morrow LE, Kollef MH: Recognition and prevention of nosocomial pneumonia in the intensive care unit and infection control in mechanical ventilation. Crit Care Med 2010, 38 (8 Suppl):S352-362.

5. Koulenti D, Lisboa T, Brun-Buisson C, Krueger W, Macor A, Sole-Violan J, Diaz E, Topeli A, DeWaele J, Carneiro A, Martin-Loeches I, Armaganidis A, Rello J; EU-VAP/CAP Study Group: Spectrum of practice in the diagnosis of nosocomial pneumonia in patients requiring mechanical ventilation in European intensive care units. Crit Care Med 2009, 37:2360-2368.

6. Infectious Diseases Society of America (IDSA); American College of Chest Physicians (ACCP); American Thoracic Society (ATS); Society of Critical Care Medicine (SCCM), Spellberg B, Talbot G: Recommended design features of future clinical trials of antibacterial agents for hospital-acquired bacterial pneumonia and ventilator-associated bacterial pneumonia. Clin Infect Dis 2010, 51 Suppl 1:S150-170.

7. Iregui M, Ward S, Sherman G, Fraser VJ, Kollef MH: Clinical importance of delays in the initiation of appropriate antibiotic treatment for ventilatorassociated pneumonia. Chest 2002, 122:262-268. 
8. Kett DH, Cano E, Quartin AA, Mangino JE, Zervos MJ, Peyrani P, Cely CM, Ford KD, Scerpella EG, Ramirez JA; the Improving Medicine through Pathway Assessment of Critical Therapy of Hospital-Acquired Pneumonia (IMPACTHAP) Investigators: Implementation of guidelines for management of possible multidrug-resistant pneumonia in intensive care: an observational, multicentre cohort study. Lancet Infect Dis 2011 Jan 19. [Epub ahead of print].

9. Johnston P, McAuley DF, O'Kane CM: Novel pulmonary biomarkers in the diagnosis of VAP. Thorax 2010, 65:190-192.

10. Gibot S, Cravoisy A, Levy B, Bene MC, Faure G, Bollaert PE: Soluble triggering receptor expressed on myeloid cells and the diagnosis of pneumonia. N Engl J Med 2004, 350:451-458.

11. Luyt CE, Combes A, Reynaud C, Hekimian G, Nieszkowska A, Tonnellier M, Aubry A, Trouillet JL, Bernard M, Chastre J: Usefulness of procalcitonin for the diagnosis of ventilator-associated pneumonia. Intensive Care Med 2008, 34:1434-1440.

12. Seligman R, Papassotiriou J, Morgenthaler NG, Meisner M, Teixeira PJ: Copeptin, a novel prognostic biomarker in ventilator-associated pneumonia. Crit Care 2008, 12:R11.

13. Linssen CF, Bekers O, Drent M, Jacobs JA: C-reactive protein and procalcitonin concentrations in bronchoalveolar lavage fluid as a predictor of ventilator-associated pneumonia. Ann Clin Biochem 2008, 45:293-298.

14. Conway Morris A, Kefala K, Wilkinson TS, Moncayo-Nieto OL, Dhaliwal K, Farrell L, Walsh TS, Mackenzie SJ, Swann DG, Andrews PJ, Anderson N, Govan JR, Laurenson IF, Reid H, Davidson DJ, Haslett C, Sallenave JM, Simpson AJ: Diagnostic importance of pulmonary interleukin-1beta and interleukin-8 in ventilator-associated pneumonia. Thorax 2010, 65:201-207.

15. Srinivasan $R$, Song $Y$, Wiener-Kronish J, Flori HR: Plasminogen activation inhibitor concentrations in bronchoalveolar lavage fluid distinguishes ventilator-associated pneumonia from colonization in mechanically ventilated pediatric patients. Pediatr Crit Care Med 2011, 12:21-27.

16. Determann RM, Millo JL, Waddy S, Lutter R, Garrard CS, Schultz MJ: Plasma CC16 levels are associated with development of ALI/ARDS in patients with ventilator-associated pneumonia: a retrospective observational study. BMC Pulm Med 2009, 9:49.

17. Seligman R, Papassotiriou J, Morgenthaler NG, Meisner M, Teixeira PJ: Prognostic value of midregional pro-atrial natriuretic peptide in ventilator-associated pneumonia. Intensive Care Med 2008, 34:2084-2091.

18. Flanagan PG, Jackson SK, Findlay G: Diagnosis of gram negative, ventilator associated pneumonia by assaying endotoxin in bronchial lavage fluid. J Clin Pathol 2001, 54:107-110.

19. el-Ebiary M, Torres A, González J, Martos A, Puig de la Bellacasa J, Ferrer M, Rodriguez-Roisin R: Use of elastin fibre detection in the diagnosis of ventilator associated pneumonia. Thorax 1995, 50:14-17.

20. Anand NJ, Zuick S, Klesney-Tait J, Kollef MH: Diagnostic implications of soluble triggering receptor expressed on myeloid cells-1 in BAL fluid of patients with pulmonary infiltrates in the ICU. Chest 2009, 135:641-647.

21. Bouadma L, Luyt CE, Tubach F, Cracco C, Alvarez A, Schwebel C, Schortgen F, Lasocki S, Veber B, Dehoux M, Bernard M, Pasquet B, Régnier B, Brun-Buisson C, Chastre J, Wolff M; PRORATA trial group: Use of procalcitonin to reduce patients' exposure to antibiotics in intensive care units (PRORATA trial): a multicentre randomised controlled trial. Lancet 2010, 375:463-474.

doi:10.1186/cc10050

Cite this article as: Fagon J-Y: Biological markers and diagnosis of ventilator-associated pneumonia. Critical Care 2011, 15:130. 